\title{
Sulfonamide Inhibition Studies of an $\alpha$-Carbonic Anhydrase from Schistosoma mansoni, a Platyhelminth Parasite Responsible for Schistosomiasis
}

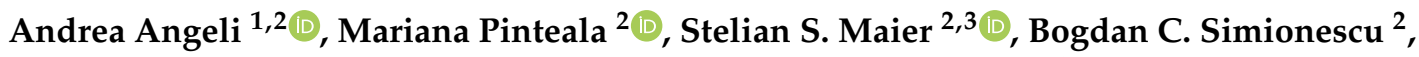 \\ Akram A. Da'dara ${ }^{4}$, Patrick J. Skelly ${ }^{4}$ and Claudiu T. Supuran ${ }^{1, *(D)}$ \\ 1 Dipartimento Neurofarba, Sezione di Scienze Farmaceutiche e Nutraceutiche, Università degli Studi di \\ Firenze, Via U. Schiff 6, 50019 Sesto Fiorentino, Florence, Italy; andrea.angeli@unifi.it \\ 2 Centre of Advanced Research in Bionanoconjugates and Biopolymers Department, "Petru Poni" Institute of \\ Macromolecular Chemistry, 700487 Iasi, Romania; pinteala@icmpp.ro (M.P.); smaier@ch.tuiasi.ro (S.S.M.); \\ bcsimion@icmpp.ro (B.C.S.) \\ 3 Polymers Research Center, Polymeric Release Systems Research Group, “Gheorghe Asachi” Technical \\ University of Iasi, 700050 Iasi, Romania \\ 4 Department of Infectious Disease and Global Health, Cummings School of Veterinary Medicine, Tufts \\ University, North Grafton, MA 01536, USA; Akram.Da_darah@tufts.edu (A.A.D.); \\ Patrick.Skelly@tufts.edu (P.J.S.) \\ * Correspondence: claudiu.supuran@unifi.it
}

Received: 5 February 2020; Accepted: 4 March 2020; Published: 7 March 2020

\begin{abstract}
Schistosomiasis is a debilitating infection provoked by parasitic flatworms called schistosomes. The species Schistosoma mansoni is endemic in Africa, where it causes intestinal schistosomiasis. Recently, an $\alpha$-carbonic anhydrase (CA, EC 4.2.1.1) was cloned and characterized from this organism and designated as SmCA. The protein is expressed in the tegument (skin) of $S$. mansoni at the host-parasite interface. Recombinant SmCA possesses high catalytic activity in the $\mathrm{CO}_{2}$ hydration reaction, similar to that of human CA isoform II with a $\mathrm{k}_{\text {cat }}$ of $1.2 \times 10^{6} \mathrm{~s}^{-1}$ and a $\mathrm{k}_{\text {cat }} / \mathrm{K}_{\mathrm{M}}$ of $1.3 \times 10^{8} \mathrm{M}^{-1} \cdot \mathrm{s}^{-1}$. It has been found that schistosomes whose SmCA gene is suppressed using RNA interference are unable to establish a robust infection in mice, suggesting that the chemicals that inhibit SmCA function should have the same debilitating effect on the parasites. In this study, a collection of aromatic/heterocyclic sulfonamides were investigated as possible SmCA inhibitors. Several sulfonamides inhibited SmCA with medium to weak potency ( $K_{I}$ values of $\left.737.2 \mathrm{nM}-9.25 \mu \mathrm{M}\right)$, whereas some heterocyclic compounds inhibited the enzyme with $\mathrm{K}_{\mathrm{I}}$ values in the range of 124-325 $\mathrm{nM}$. The $\alpha$-CA from S. mansoni, SmCA, is proposed as a new anti-schistosomiasis drug target.
\end{abstract}

Keywords: carbonic anhydrase; sulfonamide; schistosomiasis; Schistosoma mansoni; inhibitor; trematode; blood fluke

\section{Introduction}

Carbonic anhydrases (CAs, EC 4.2.1.1) are ubiquitous metallo-enzymes present in all kingdoms of life [1-3]. To date, eight distinct and genetically independent $C A$ classes are known, and these are classified as $\alpha-, \beta-, \gamma-, \delta-, \zeta-, \eta-, \theta$ and, เ- isoforms [4-8]. This superfamily of enzymes catalyzes the same physiologically reversible reaction: the conversion of carbon dioxide $\left(\mathrm{CO}_{2}\right)$ to bicarbonate $\left({ }^{-} \mathrm{HCO}_{3}\right)$ and protons $\left(\mathrm{H}^{+}\right)$[9]. This important physiological reaction plays a key role in several biosynthetic pathways, such as the biosynthesis of fatty acids, amino acids and nucleotides [10-12]. In recent years, CAs have been investigated in detail in pathogens such as bacteria and protozoa [13-16]. One aim 
of such work is the search for new antibiotics and anti-infectives that exhibit novel mechanisms of action [17-20]. In this context, schistosomiasis, a tropical disease caused by trematode parasites of the genus Schistosoma, has been neglected. The disease is considered to be the second most debilitating parasitic infection in terms of morbidity and mortality, after malaria [21,22]. Indeed, schistosomes are estimated to currently infect more than 206 million people worldwide, and over 700 million people live in areas where the disease is endemic [23]. Schistosomiasis is prevalent in tropical and subtropical areas, particularly in poor communities that lack access to safe drinking water and adequate sanitation. The current treatment for infection is centered on the drug praziquantel [24]. However, the exclusive use of praziquantel has been accompanied by reports in the literature that parasites isolated from some patients have been resistant to treatment $[25,26]$. The possibility of developing new anti-schistosomiasis agents with a novel mechanism of action has come to the fore in light of the fact that an $\alpha$-CA isoform designated as SmCA has recently been identified and characterized from S. mansoni. SmCA is a $\sim 37 \mathrm{kDa}$ GPI-linked glycoprotein that is expressed in the tegument (skin) of $S$. mansoni at the host-parasite interface [19]. Such proteins are considered as good drug targets given their accessibility-they are foundon the surface of worms. The SmCA gene is expressed in all schistosome life stages examined, with the highest relative expression seen in adult male worms [19]. Schistosomes whose SmCA gene is suppressed using RNAi have been found to be unable to establish a robust infection in mice [19]. This suggests that chemicals that inhibit SmCA function will have the same debilitating effect on the parasites and could curtail infection [19]. In this work, a collection of 24 aromatic/heterocyclic sulfonamide compounds were tested for their ability to block the enzymatic action of recombinant SmCA (that has been produced and purified from CHO-S cells) [19]. The long-term aim of this work is to identify potent SmCA-blocking compounds that can incapacitate schistosomes and cure infection.

\section{Results}

The SmCA catalytic activity for the $\mathrm{CO}_{2}$ hydration reaction is shown in Table 1; data for other CAs, such as the widespread and well-investigated human (h) isoforms hCA I and hCA II, as well as the Trypanosoma cruzi enzyme (TcCA, belonging to the $\alpha$-class [27]), and a $\beta$-CA from Leishmania donovani (LdCA) [28], are included for comparison. A stopped-flow $\mathrm{CO}_{2}$ hydrase assay was used to measure the catalytic activity of these enzymes under identical conditions [29].

Table 1. Kinetic parameters for the $\mathrm{CO}_{2}$ hydration reaction catalyzed by platyhelminth SmCA (green row) as well as the $\alpha$-CA isozymes of human (h) hCA I and hCA II, protozoan Trypanosoma cruzi enzyme (TcCA) and Leishmania donovani (LdCA) at $20{ }^{\circ} \mathrm{C}, \mathrm{pH} 7.5$ (for the $\alpha$-CAs) and $\mathrm{pH} 8.4$ (for the $\beta$-CA). Inhibition data ( $\mathrm{K}_{\mathrm{I}}$ values) generated with the clinically used drug Acetazolamide (AAZ, 5-Acetamido-1,3,4-thiadiazole-2-sulfonamide) are shown in the right-hand column.

\begin{tabular}{ccccc}
\hline Enzyme & $\mathbf{k}_{\text {cat }}\left(\mathbf{s}^{\mathbf{- 1}}\right)$ & $\mathbf{K}_{\mathbf{m}} \mathbf{( M )}$ & $\mathbf{k}_{\mathbf{c a t}} / \mathbf{K}_{\mathbf{m}} \mathbf{( \mathbf { M } ^ { - 1 } \cdot \mathbf { s } ^ { - \mathbf { 1 } } )}$ & $\mathbf{K}_{\mathbf{I}} \mathbf{( A A Z )}(\mathbf{n M})$ \\
\hline hCA I $^{\mathrm{a}}$ & $2.00 \times 10^{5}$ & $4.0 \times 10^{-3}$ & $5.00 \times 10^{7}$ & 250.0 \\
hCA II $^{\mathrm{a}}$ & $1.40 \times 10^{6}$ & $9.3 \times 10^{-3}$ & $1.50 \times 10^{8}$ & 12.1 \\
TcCA $^{\mathrm{b}}$ & $1.21 \times 10^{6}$ & $8.1 \times 10^{-3}$ & $1.49 \times 10^{8}$ & 61.6 \\
LdCA $^{\mathrm{c}}$ & $9.35 \times 10^{5}$ & $15.8 \times 10^{-3}$ & $5.9 \times 10^{7}$ & 91.7 \\
SmCA $^{\mathrm{d}}$ & $1.2 \times 10^{6}$ & $9.2 \times 10^{-3}$ & $1.3 \times 10^{8}$ & 42.5 \\
\hline
\end{tabular}

All experiments employed recombinant isozymes and used the stopped-flow $\mathrm{CO}_{2}$ hydrase assay method a $[3,4]$, b,c $[27,28],{ }^{\mathrm{d}}[19]$.

SmCA has kinetic parameters similar to human isoform hCA II, one of the most catalytically active enzymes known [3]. Indeed, with a kcat/Km of $1.3 \times 10^{8} \mathrm{M}^{-1} \cdot \mathrm{s}^{-1}$, SmCA has basically indistinguishable kinetic parameters compared to both hCA II and to the protozoa $\alpha$-CA TcCA (Table 1). All three are much more active as a catalyst for $\mathrm{CO}_{2}$ hydration compared to hCA I or the $\beta$-class CA, LdCA. However, SmCA is much less sensitive to the sulfonamide inhibitor acetazolamide (5-acetamido-1,3,4-thiadiazole-2-sulfonamide,AAZ) compared to all the other CAs tested. 
Sulfonamides are the main class of zinc-binding CA inhibitors (CAIs), [2,3] but several other classes of inhibitors have also been reported recently, such as the thiols, dithiocarbamates, coumarins, polyamines and selenols among others [30,31]. We have thus included a range of sulfonamides in an initial screening program to find the compounds targeting this new protozoan enzyme. Sulfonamides, thiols, dithiocarbamates and selenols possess a similar mechanism of action, as they bind to the zinc ion within the active site cavity and substitute the non-protein zinc ligand (the hydroxide ion/water molecule) [2,3,30,31]. Here, we investigated a panel of 24 sulfonamides (compounds 1-24, whose molecular structure is depicted in Figure 1) for their ability to inhibit recombinant SmCA (rSmCA). Table 2 presents the results of this analysis: the data for SmCA (highlighted in green) are compared to those generated with human isoforms hCA I and hCA II and the CAs from the protozoan parasites $T$. cruzi (TcCA) and L. donovani (LdCA).

Table 2. Inhibition of S. mansoni SmCA (green column) compared with human carbonic anhydrase isoforms hCA I and hCA II, as well as protozoan CAs from T. cruzi (TcCA) and L. donovani (LdCA), using sulfonamides 1-24 and as assessed by the stopped-flow $\mathrm{CO}_{2}$ hydrase assay [29].

\begin{tabular}{cccccc}
\hline \multicolumn{5}{c}{$\mathbf{K}_{\mathbf{I}}(\mathbf{n M})^{*}$} \\
\hline Inhibitor & hCA I $^{\mathbf{a}}$ & hCA II $^{\mathbf{a}}$ & SmCA $^{\mathbf{b}}$ & TcCA $^{\mathbf{c}}$ & LdCA $^{\mathbf{d}}$ \\
\hline $\mathbf{1}$ & 45400 & 295.0 & $8423 \pm 177$ & 25460 & 5960 \\
$\mathbf{2}$ & 25000 & 240.0 & $6819 \pm 150$ & 57300 & 9251 \\
$\mathbf{3}$ & 28000 & 300.0 & $915.6 \pm 23.8$ & 63800 & 8910 \\
$\mathbf{4}$ & 78500 & 320.0 & $4534 \pm 90$ & 44200 & $>10000$ \\
$\mathbf{5}$ & 25000 & 170.0 & $9558 \pm 191$ & 7231 & $>10000$ \\
$\mathbf{6}$ & 21000 & 160.0 & $7242 \pm 144$ & 9238 & $>10000$ \\
$\mathbf{7}$ & 8300 & 60.0 & $3190 \pm 70$ & 8130 & 15600 \\
$\mathbf{8}$ & 9800 & 110.0 & $737.2 \pm 19.1$ & 6925 & 9058 \\
$\mathbf{9}$ & 6500 & 40.0 & $807.7 \pm 16.9$ & 8520 & 8420 \\
$\mathbf{1 0}$ & 6000 & 70.0 & $9268 \pm 185$ & 9433 & 9135 \\
$\mathbf{1 1}$ & 5800 & 63.0 & $183.1 \pm 9.1$ & 842 & 9083 \\
$\mathbf{1 2}$ & 8400 & 75.0 & $644.8 \pm 19.9$ & 820 & 4819 \\
$\mathbf{1 3}$ & 8600 & 60.0 & $137.4 \pm 6.5$ & 534 & 584 \\
$\mathbf{1 4}$ & 9300 & 19.0 & $325.1 \pm 6.5$ & 652 & 433 \\
$\mathbf{1 5}$ & 6.0 & 2.0 & $758.2 \pm 26.5$ & 73880 & 927 \\
$\mathbf{1 6}$ & 164.0 & 46.0 & $1462 \pm 32.1$ & 71850 & 389 \\
$\mathbf{1 7}$ & 185.0 & 50.0 & $605.6 \pm 21.3$ & 66750 & 227 \\
$\mathbf{1 8}$ & 109.0 & 33.0 & 820.7 & 84000 & 59.6 \\
$\mathbf{1 9}$ & 95.0 & 30.0 & $1831 \pm 36.6$ & 810 & $>10000$ \\
$\mathbf{2 0}$ & 690.0 & 12.0 & $124.2 \pm 5.9$ & 88.5 & 95.1 \\
$\mathbf{2 1}$ & 55.0 & 80.0 & $163.2 \pm 6.5$ & 134 & 50.2 \\
$\mathbf{2 2}$ & 21000 & 125.0 & $550.4 \pm 14.8$ & 365 & 136 \\
$\mathbf{2 3}$ & 23000 & 133.0 & $523.7 \pm 15.7$ & 243 & 87.1 \\
$\mathbf{2 4}$ & 24000 & 125.0 & $183.5 \pm 4.5$ & 192 & 73.4 \\
$\mathbf{A A Z}$ & 250.0 & 12.1 & 42.5 & 61.6 & 91.7 \\
\hline
\end{tabular}

* The data represents the mean of three different assays; the mean errors are $\pm 2-5 \%$ of the reported values. All experiments employed recombinant isozymes and used the stopped-flow $\mathrm{CO}_{2}$ hydrase assay method a [3,4]. ${ }^{\mathrm{b}, \mathrm{c}}$ $[26,27],{ }^{d}[19]$.

The sulfonamides 1-24 and AAZ investigated in this study were either commercially available or prepared in the manner that was reported earlier by our group [27,28].

Several of the simple sulfonamides investigated here, such as compounds 1, 2, 4-7 and 10, were weakly inhibitory, with $\mathrm{K}_{\mathrm{I}}$ values of 3.1-9.5 $\mu \mathrm{M}$. Note that all these compounds are aromatic derivatives with incorporation of an amine group (Figure 1). More effective inhibition of SmCA is observed with the remaining compounds with primary amine groups such as 8, 9, 11 and 12 with $\mathrm{K}_{\mathrm{I}}$ values in the range $137-807 \mathrm{nM}$ (Table 2). Note that these compounds belong to a rather heterogeneous class of aromatic sulfonamides, so the structure-activity relationship (SAR) is not straightforward. On the other hand, 
the heterocycle compounds 13, 14 and 20 were better inhibitors than the benzenesulfonamide scaffold, with $\mathrm{K}_{\mathrm{I}}$ spanning between $124.2-325.1 \mathrm{nM}$.<smiles>Nc1cccc(S(N)(=O)=O)c1</smiles>

1<smiles>NCc1ccc(S(N)(=O)=O)cc1</smiles>

5<smiles>Nc1ccc(S(N)(=O)=O)cc1Br</smiles>

9<smiles>Nc1ccc(S(N)(=O)=O)cc1</smiles><smiles>NCCc1ccc(S(N)(=O)=O)cc1</smiles>

6<smiles>NS(=O)(=O)c1cc(Cl)cc(Cl)c1O</smiles>

10<smiles>NS(=O)(=O)c1cccc(S(N)(=O)=O)c1</smiles>

3<smiles>Nc1ccc(S(N)(=O)=O)cc1F</smiles>

7<smiles>Cc1ccc(S(=O)(=O)ON)cc1</smiles>

4<smiles>Nc1ccc(S(N)(=O)=O)cc1Cl</smiles>

8<smiles>Nc1cc(C(F)(F)F)c(S(N)(=O)=O)cc1S(N)(=O)=O</smiles>

11<smiles>Nc1cc(Cl)c(S(N)(=O)=O)cc1S(N)(=O)=O</smiles>

12<smiles>Nc1nnc(S(N)(=O)=O)s1</smiles>

13<smiles>Cn1nc(S(N)(=O)=O)sc1=N</smiles>

14<smiles>NS(=O)(=O)c1ccc(CCO)cc1</smiles>

15: $n=0$

16: $\mathrm{n}=1$

17: $n=2$<smiles>NS(=O)(=O)c1ccc(C(=O)O)cc1</smiles>

18<smiles>Nc1nccc(Nc2ccc(S(N)(=O)=O)cc2)n1</smiles>

19<smiles>Nc1ccc(S(=O)(=O)Nc2nnc(S(N)(=O)=O)s2)cc1</smiles>

20<smiles>NS(=O)(=O)c1ccc(CCNS(=O)(=O)c2ccc([N+](=O)[O-])cc2CO)cc1</smiles>

21<smiles>CC(NS(=O)(=O)c1ccc(N)cc1)c1ccc(S(N)(=O)=O)cc1</smiles>

22: $\mathrm{n}=0$

23: $n=1$

24: $n=2$

Figure 1. Structures 1-24. 
Modifications to the tail moiety of the inhibitors 15-17 and 22-24 followed the "tail approach", which involves modifying the tails of the well-known aromatic sulfonamide scaffolds in order to modulate the physicochemical properties, such as the water solubility and enzyme-binding capacity of these pharmacological agents. Indeed, the tail length of the compounds 15-17 is optimal for derivative 17 with an ethyl chain $\left(\mathrm{K}_{\mathrm{I}}\right.$ 605.6). The inhibition activity of the compounds $\mathbf{2 2 - 2 4}$ exhibited the same inhibition feature, showing the best activity with an ethyl chain (24) with $\mathrm{K}_{\mathrm{I}}$ of $183.5 \mathrm{nM}$. While the inhibition profile of the schistosome enzyme SmCA was very different from that of the mammalian enzymes hCA I and hCA II, none of the tested compounds showed greater inhibition of the worm enzyme when compared to both human isoforms (Table 2).

\section{Materials and Methods}

\subsection{General}

Compounds 1-24 were commercially available, high-purity reagents from Sigma-Aldrich, Milan, Italy. SmCA, TcCA and LdCA were recombinant proteins produced using the methods previously reported by our groups $[19,27,28]$.

\subsection{Carbonic Anhydrase Assay}

A stopped-flow method [29] was used to assay CA-catalyzed $\mathrm{CO}_{2}$ hydration activity with Phenol red as an indicator, working at the absorbance maximum of $557 \mathrm{~nm}$, following the initial rates of the reaction for 10-100 s. For each inhibitor, at least six traces of the initial 5-10\% of the reaction were used to determine the initial velocity (see Supplementary Materials). The uncatalyzed rates were determined in the same manner and subtracted from the total observed rates. Stock solutions of inhibitor $(0.01$ $\mathrm{mM}$ ) were prepared in distilled-deionized water with 5\% DMSO and dilutions up to $0.1 \mathrm{nM}$ were performed thereafter with a buffer. The inhibition constant $\left(\mathrm{K}_{\mathrm{I}}\right)$ of each tested compound was obtained by considering the classical Michaelis-Menten equation, which was fitted by non-linear least squares using PRISM 3 software.

\subsection{Expression and Purification of Recombinant SmCA}

The full-length coding sequence of SmCA (GenBank accession number, MK611932), including the predicted signal peptide and glycophosphatidylinositol (GPI) anchor domain, was codon optimized using hamster codon preferences and synthesized commercially (Genscript). Next, the region encoding the amino acids N21-A298 (i.e., lacking the amino terminal signal peptide and the carboxyl terminal GPI-anchoring signal) was generated by polymerase chain reaction (PCR) using forward and reverse primers containing AscI and XhoI restriction sites, respectively, and the synthetic codon-optimized gene as a template. The amplified product was cloned into the pSecTag2A plasmid (Invitrogen, Waltham, MA, USA) at the AscI and XhoI sites in frame with the Igk leader sequence at the $5^{\prime}$-end and a myc epitope and 6-histidine tag at the 3 '-end. Successful in-frame cloning was confirmed by sequencing at the Tufts University Core Facility. To express recombinant SmCA (rSmCA), suspension-adapted Free-Style Chinese Hamster Ovary Cells (CHO-S) were transfected with plasmid using the Free-Style Max Reagent following the manufacturer's instructions (Invitrogen). Cells were harvested at various time points post-transfection to monitor viability (by the trypan blue exclusion test) and rSmCA expression (by Western blotting). To facilitate protein production, stable cell line clones secreting rSmCA were selected by treating transfected cells with $250 \mu \mathrm{g} / \mathrm{mL}$ of Zeocin for two weeks; individual clones that produced high yields $(5-10 \mathrm{mg}$ ) of purified active $\mathrm{rSmCA} / \mathrm{L}$ were maintained. Recombinant SmCA was purified from the cell culture medium by standard Immobilized Metal Affinity Chromatography (IMAC) using HisTrap ${ }^{\mathrm{TM}}$ Excel columns, following the manufacturer's instructions (GE Healthcare Life Sciences, Chicago, IL, USA). Purified recombinant protein, eluted from the column, was dialyzed overnight at $4{ }^{\circ} \mathrm{C}$ against $50 \mathrm{mM}$ Tris- $\mathrm{HCl}(\mathrm{pH} 7.4), 150 \mathrm{mM} \mathrm{NaCl}$, then concentrated by ultrafiltration centrifugation (Pierce Protein Concentrators, 10 K MWCO, Thermo Scientific, Waltham, MA, USA). Final protein 
concentration was determined using a BCA Protein Assay Kit (Pierce, Waltham, Massachusetts, USA). Aliquots of eluted protein were resolved by $4-20 \%$ SDS-PAGE to assess purity, and some were tested for specificity by Western blotting using anti-myc tag and anti-SmCA antibodies.

\section{Conclusions}

We report the inhibition profile of the $\alpha$-CA from the platyhelminth parasite $S$. mansoni, a causative agent of schistosomiasis. This enzyme, SmCA, showed a high catalytic activity for the $\mathrm{CO}_{2}$ hydration reaction, being similar kinetically to $\alpha$-CA from the protozoan T. cruzi and the human isoform hCA II. A library of aromatic/heterocyclic sulfonamides were investigated as possible SmCA inhibitors. The aromatic sulfonamides were, generally, weak inhibitors ( $\mathrm{K}_{\mathrm{I}}$ values of $\left.737.2 \mathrm{nM}-9.25 \mu \mathrm{M}\right)$, whereas some heterocyclic compounds inhibited this enzyme, with $K_{I}$ values in the range of $124.2-325.1 \mathrm{nM}$. However, no compounds were identified in this chemical screen that preferentially inhibited SmCA to a greater degree than the human CAs. The overall inhibition profile of the schistosome enzyme differed substantially from those of the human isoforms tested, and this highlights the different biochemistries of the parasite versus the host enzymes. These results are not unexpected given that crystal structure comparisons of the worm versus the human enzymes has revealed differences in the active sites (and other regions) of the proteins [19]. These differences suggest that it will be possible to identify chemicals that selectively and potently block SmCA action while exerting little or no inhibition of human homologs. Indeed, a number of compounds (phenylarsonic acid, phenylbaronic acid, sulfamide) have been shown to exhibit substantially more favorable $\mathrm{K}_{\mathrm{I}} \mathrm{s}$ for SmCA versus the human isoforms [19]. Thus, we believe that SmCA is an important target for developing anti-parasitic trematode drugs that exert a novel mechanism of action.

Supplementary Materials: The following are available online at http://www.mdpi.com/1422-0067/21/5/1842/s1, Carbonic Anhydrase activity.

Author Contributions: Investigation, A.A. and A.A.D.; data curation, P.J.S.; writing-original draft preparation, A.A.; writing - review and editing, C.T.S. and P.J.S.; funding acquisition, M.P., S.S.M. and B.C.S. All authors have read and agreed to the published version of the manuscript.

Funding: This work was supported by a grant of the Romanian Ministry of Research and Innovation, CNCS-UEFISCDI, project number PN-III-P4-ID-PCCF-2016-0050, within PNCDI II and by grants AI-056273 and AI-111011 from the National Institutes of Health - National Institute of Allergy and Infectious Diseases (NIH-NIAID).

Conflicts of Interest: The authors declare no conflict of interest.

\section{Abbreviations}

$\begin{array}{ll}\text { CA } & \text { Carbonic Anhydrase } \\ \text { CAI } & \text { Carbonic Anhydrase Inhibitors } \\ \text { SmCA } & \text { Schistosoma Mansoni Carbonic Anhydrase } \\ \text { DMSO } & \text { Dimethylsulfoxide }\end{array}$

\section{References}

1. Supuran, C.T. Structure and function of carbonic anhydrases. Biochem. J. 2016, 473, 2023-2032. [CrossRef]

2. Supuran, C.T. Carbonic anhydrase inhibitors and their potential in a range of therapeutic areas. Expert Opin. Ther. Pat. 2018, 28, 709-712. [CrossRef]

3. Supuran, C.T. Advances in structure-based drug discovery of carbonic anhydrase inhibitors. Expert Opin. Drug Discov. 2017, 12, 61-88. [CrossRef]

4. Neri, D.; Supuran, C.T. Interfering with $\mathrm{pH}$ regulation in tumours as a therapeutic strategy. Nat. Rev. Drug Discov. 2011, 10, 767-777. [CrossRef] [PubMed]

5. Capasso, C.; Supuran, C.T. An overview of the alpha-, beta-and gamma-carbonic anhydrases from Bacteria: Can bacterial carbonic anhydrases shed new light on evolution of bacteria? J. Enzyme Inhib. Med. Chem. 2015, 30, 325-332. [CrossRef] [PubMed] 
6. Del Prete, S.; Vullo, D.; Fisher, G.M.; Andrews, K.T.; Poulsen, S.A.; Capasso, C.; Supuran, C.T. Discovery of a new family of carbonic anhydrases in the malaria pathogen Plasmodium falciparum-the $\eta$-carbonic anhydrases. Bioorg. Med. Chem. Lett. 2014, 24, 4389-4396. [CrossRef]

7. Angeli, A.; Pinteala, M.; Maier, S.S.; Del Prete, S.; Capasso, C.; Simionescu, B.C.; Supuran, C.T. Inhibition of $\alpha-, \beta-, \gamma_{-}, \delta-, \zeta-$ and $\eta$-class carbonic anhydrases from bacteria, fungi, algae, diatoms and protozoans with famotidine. J. Enzyme Inhib. Med. Chem. 2019, 34, 644-650. [CrossRef] [PubMed]

8. Jensen, E.L.; Clement, R.; Kosta, A.; Maberly, S.C.; Gontero, B. A new widespread subclass of carbonic anhydrase in marine phytoplankton. ISME J. 2019, 13, 2094-2106. [CrossRef] [PubMed]

9. Supuran, C.T. Carbonic anhydrases: Novel therapeutic applications for inhibitors and activators. Nat. Rev. Drug Discov. 2008, 7, 168-181. [CrossRef] [PubMed]

10. Supuran, C.T. Carbonic anhydrases: From biomedical applications of the inhibitors and activators to biotechnological use for $\mathrm{CO}_{2}$ capture. J. Enzyme Inhib. Med. Chem. 2013, 28, 229-230. [CrossRef] [PubMed]

11. Supuran, C.T. How many carbonic anhydrase inhibition mechanisms exist? J. Enzyme Inhib. Med. Chem. 2016, 31, 345-360. [CrossRef] [PubMed]

12. Alterio, V.; Di Fiore, A.; D'Ambrosio, K.; Supuran, C.T.; De Simone, G. Multiple binding modes of inhibitors to carbonic anhy-drases: How to design specific drugs targeting 15 differentisoforms? Chem. Rev. 2012, 112, 4421-4468. [CrossRef] [PubMed]

13. Angeli, A.; Pinteala, M.; Maier, S.S.; Del Prete, S.; Capasso, C.; Simionescu, B.C.; Supuran, C.T. Inhibition of bacterial $\alpha-, \beta$ - and $\gamma$-class carbonic anhydrases with selenazoles incorporating benzenesulfonamide moieties. J. Enzyme Inhib. Med. Chem. 2019, 34, 244-249. [CrossRef]

14. Angeli, A.; Ferraroni, M.; Supuran, C.T. Famotidine, an Antiulcer Agent, Strongly Inhibits Helicobacter pylori and Human Carbonic Anhydrases. ACS Med. Chem. Lett. 2018, 9, 1035-1038. [CrossRef] [PubMed]

15. Angeli, A.; Abbas, G.; Del Prete, S.; Capasso, C.; Supuran, C.T. Selenides bearing benzenesulfonamide show potent inhibition activity against carbonic anhydrases from pathogenic bacteria Vibrio cholerae and Burkholderia pseudomallei. Bioorg. Chem. 2018, 79, 319-322. [CrossRef] [PubMed]

16. Angeli, A.; Abbas, G.; Del Prete, S.; Carta, F.; Capasso, C.; Supuran, C.T. Acyl selenoureido benzensulfonamides show potent inhibitory activity against carbonic anhydrases from the pathogenic bacterium Vibrio cholerae. Bioorg. Chem. 2017, 75, 170-172. [CrossRef] [PubMed]

17. Al-Tamimi, A.S.; Etxebeste-Mitxeltorena, M.; Sanmartín, C.; Jiménez-Ruiz, A.; Syrjänen, L.; Parkkila, S.; Selleri, S.; Carta, F.; Angeli, A.; Supuran, C.T. Discovery of new organoselenium compounds as antileishmanial agents. Bioorg. Chem. 2019, 86, 339-345. [CrossRef] [PubMed]

18. Llanos, M.A.; Sbaraglini, M.L.; Villalba, M.L.; Ruiz, M.D.; Carrillo, C.; Soto, C.A.; Talevi, A.; Angeli, A.; Parkkila, S.; Supuran, C.T.; et al. A structure-based approach towards the identification of novel antichagasic compounds: Trypanosoma cruzi carbonic anhydrase inhibitors. J. Enzyme Inhib. Med. Chem. 2020, 35, 21-30. [CrossRef]

19. Da'dara, A.A.; Angeli, A.; Ferraroni, M.; Supuran, C.T.; Skelly, P.J. Crystal structure and chemical inhibition of essential schistosome host-interactive virulence factor carbonic anhydrase SmCA. Commun. Biol. 2019, 2, 333. [CrossRef]

20. Del Prete, S.; Angeli, A.; Ghobril, C.; Hitce, J.; Clavaud, C.; Marat, X.; Supuran, C.T.; Capasso, C. Anion Inhibition Profile of the $\beta$-Carbonic Anhydrase from the Opportunist Pathogenic Fungus Malassezia Restricta Involved in Dandruff and Seborrheic Dermatitis. Metabolites 2019, 9, 147. [CrossRef]

21. Swain, M.T.; Larkin, D.M.; Caffrey, C.R.; Davies, S.J.; Loukas, A.; Skelly, P.J.; Hoffmann, K.F. Schistosoma comparative genomics: Integrating genome structure, parasite biology and anthelmintic discovery. Trends Parasitol. 2011, 27, 555-564. [CrossRef] [PubMed]

22. Da'dara, A.A.; Faghiri, Z.; Krautz-Peterson, G.; Bhardwaj, R.; Skelly, P.J. Schistosome Na,K-ATPase as a therapeutic target. Trans. R. Soc. Trop. Med. Hyg. 2013, 107, 74-82. [CrossRef] [PubMed]

23. Schistosomiasis-World Health Organization. Available online: https://www.who.int/news-room/factsheets/detail/schistosomiasis (accessed on 20 February 2019).

24. Siqueira, L.D.; Fontes, D.A.F.; Aguilera, C.S.B.; Timoteo, T.R.R.; Angelos, M.A.; Silva, L.C.P.B.B.; de Melo, C.G.; Rolim, L.A.; da Silva, R.M.F.; Neto, P.J.R. Schistosomiasis: Drugs used and treatment strategies. Acta Trop. 2017, 176, 179-187. [CrossRef] [PubMed]

25. Doenhoff, M.J.; Cioli, D.; Utzinger, J. Praziquantel: Mechanisms of action, resistance and new derivatives for schistosomiasis. Curr. Opin. Infect. Dis. 2008, 21, 659-667. [CrossRef] 
26. Wang, W.; Wang, L.; Liang, Y.S. Susceptibility or resistance of praziquantel in human schistosomiasis: A review. Parasitol. Res. 2012, 111, 1871-1877. [CrossRef]

27. Pan, P.; Vermelho, A.B.; Capaci Rodrigues, G.; Scozzafava, A.; Tolvanen, M.E.; Parkkila, S.; Capasso, C.; Supuran, C.T. Cloning, characterization, and sulfonamide and thiol inhibition studies of an $\alpha$-carbonic anhydrase from Trypanosoma cruzi, the causative agent of Chagas disease. J. Med. Chem. 2013, 56, 1761-1771. [CrossRef]

28. Syrjänen, L.; Vermelho, A.B.; Rodrigues Ide, A.; Corte-Real, S.; Salonen, T.; Pan, P.; Vullo, D.; Parkkila, S.; Capasso, C.; Supuran, C.T. Cloning, characterization, and inhibition studies of a $\beta$-carbonic anhydrase from Leishmania donovani chagasi, the protozoan parasite responsible for leishmaniasis. J. Med. Chem. 2013, 56, 7372-7381. [CrossRef]

29. Khalifah, R.G. The carbon dioxide hydration activity of carbonic anhydrase. I. Stop-flow kinetic studies on the native human isoenzymes B and C. J. Biol. Chem. 1971, 246, 2561-2573.

30. Angeli, A.; Tanini, D.; Nocentini, A.; Capperucci, A.; Ferraroni, M.; Gratteri, P.; Supuran, C.T. Selenols: A new class of carbonic anhydrase inhibitors. Chem. Commun. 2019, 55, 648-651. [CrossRef]

31. Tanini, D.; Capperucci, A.; Ferraroni, M.; Carta, F.; Angeli, A.; Supuran, C.T. Direct and straightforward access to substituted alkyl selenols as novel carbonic anhydrase inhibitors. Eur. J. Med. Chem. 2019, 185, 111811. [CrossRef]

(C) 2020 by the authors. Licensee MDPI, Basel, Switzerland. This article is an open access article distributed under the terms and conditions of the Creative Commons Attribution (CC BY) license (http://creativecommons.org/licenses/by/4.0/). 